\title{
CDCA7 wt Allele
}

National Cancer Institute

\section{Source}

National Cancer Institute. CDCA7 wt Allele. NCI Thesaurus. Code C152969.

Human CDCA7 wild-type allele is located in the vicinity of 2 q31.1 and is approximately 15 $\mathrm{kb}$ in leng th. This allele, which encodes cell division cycle-associated protein 7, plays a role in the regulation of cell proliferation. Mutation of the gene is associated with immunodeficiency-centromeric instability-facial anomalies syndrome 3. 